\title{
THE PROFITABILITY OF DISPOSING OF VEHICLES FULFILLING THE OLDER EURO STANDARDS IN TERMS OF $\mathrm{CO}_{2}$ EMISSION
}

\author{
Maciej Menes \\ Motor Transport Institute, Economic Research Department \\ Jagiellonska Street 80, 03-301 Warsaw, Poland \\ tel.: +48224385287 \\ e-mail:maciej.menes@its.waw.pl \\ Piotr Wiśniowski \\ Motor Transport Institute, Environment Protection Centre \\ Jagiellonska Street 80, 03-301 Warsaw, Poland \\ tel.: +48224385265 \\ e-mail: piotr.wisniowski@its.waw.pl
}

\begin{abstract}
The automotive market is developing very dynamically. In recent years, we can observe activities of automotive concerns in the production of new models of electric, hybrid and hydrogen vehicles, and conventional cars are supplied with increasingly economical and low-emission engines. There are also increasingly stringent standards related to exhaust emissions from the exhaust system. From September 1, 2018, passenger cars have to comply with the Euro 6d-Temp emission standard and be homologated according to the WLTP test procedure including the WLTC driving cycle and emission measurements in road traffic conditions. The exhaust components measured during the test, such as carbon oxides, nitrogen oxides or hydrocarbons, are toxic to living organisms. However, it seems that the most important issue in the long term may be the value of carbon dioxide emissions, the excess of which poses an ecological threat to the entire planet. The production of new vehicles equipped with modern complicated combustion engines, batteries, fuel cells and electronic devices is associated with a very high emission of this greenhouse gas The authors of the following article, based on their own research, sought to estimate the ecological profitability of replacing a used passenger car meeting the Euro-4 emissions standard for a new vehicle bearing in mind the value of carbon dioxide emissions during vehicle production. The analysis was to indicate how intensive the annual operation of the vehicle should be to make it profitable to recycle and replace it with a modern car with lower emissions considering the global sum of carbon dioxide emissions.
\end{abstract}

Keywords: $\mathrm{CO}_{2}$ emission, exhaust gasses, cars, engines

\section{Introduction}

The use of motor vehicles has certain consequences: economic, social, and ecological. In recent years, particular attention has been paid to the ecological aspects of car use. This is due to the fact that components such as carbon oxides, nitrogen oxides, or hydrocarbons released by internal combustion engines are toxic to living organisms. However, it seems that the most important longterm issue may be the value of carbon dioxide emissions, the excess of which poses an ecological threat to the entire planet.

The increase in the concentration of carbon dioxide in the atmosphere is the cause of a number of adverse phenomena, including global warming. Global $\mathrm{CO}_{2}$ emissions, in the years 1990-2010, increased around $49 \%[1,10]$. In the same years, the average reduction of $\mathrm{CO}_{2}$ emissions for European Union countries was $12 \%$.

Officials of the European Union responsible for transport and environmental policy introduce increasingly restrictive standards related to exhaust emissions from the exhaust system. From 1 
September 2018, passenger cars registered in the European Union must comply with the Euro 6dTemp emission standard and be homologated according to the WLTP test procedure including the WLTC driving cycle and measurements of emissions in road traffic conditions. In recent years, we can observe activities of automotive concerns in the production of new models of electric, hybrid and hydrogen vehicles, and conventional cars are supplied with increasingly economical and lowemission engines. This is of course related to the new EU emission standards.

However, both officials and, above all, car buyers and the general public are missing the fact that the emissivity of the vehicle during its use by the buyer is just one of many, not the most important component, the total environmental impact of the vehicle throughout the product life cycle. It should be noted that the production of new vehicles equipped with modern, complicated combustion engines and electronic devices is associated with very high emission of carbon dioxide. The high emission of this greenhouse gas is particularly high in the case of the production of hybrid and electric cars equipped with high capacity batteries. The ecological impact of a new vehicle on the environment starts much earlier than the finished product leaves the company's production line. With serious carbon dioxide emission, we are already struggling at the stage of extracting raw materials necessary for the production of a car, through the whole production process, to transporting the finished car to the dealer's salon.

The above situation is profitable from the economic point of view for producers - they present mass production of new passenger cars and the replacement of a car park by buyers as a proecological activity. In fact, it can only be an advertising gimmick or procedure in the field of public relations, because the carbon dioxide emission associated with the creation of a new passenger car is extremely high $[1,2]$.

It is also worth noting that the cumulative $\mathrm{CO}_{2}$ emission in the production of a passenger car is directly proportional to its own weight. It should be emphasized at this point that despite the increasing use of lightweight materials for car construction, the own weight of subsequent models over the years 1990-2019 increased by a dozen or even more than 20 percent. In 1990, the average compact class car weighed $1000 \mathrm{~kg}$ - today it is usually around $1200 \mathrm{~kg}$ and more. In 1990, the average middle class car weighed about $1100-1200 \mathrm{~kg}$; today it is usually about $1400 \mathrm{~kg}$.

The cumulative $\mathrm{CO}_{2}$ emissions occurring in the construction phase of the VW Golf class car in 1990 are 4.1 tons, while its equivalent in 2000 is 4.3 tons of $\mathrm{CO}_{2} /$ vehicle [2]. It is assumed that the $\mathrm{CO}_{2}$ emission associated with the production of a modern $\mathrm{B} / \mathrm{C}$ class car is 5.6 tons of $\mathrm{CO}_{2} /$ vehicle [4].

What is also worth noting, despite the fact that the cumulative energy inputs occurring in the construction phase of passenger cars from 1990 and 2000 decreased, the summary of cumulative $\mathrm{CO}_{2}$ emissions occurring in the construction phase of these cars indicates their upward trend (with the same mass of the compared passenger car). The cumulative emissions of noxious $\mathrm{SO}_{2}$ and $\mathrm{NO}_{\mathrm{x}}$ gases occurring in the construction phase of a passenger car, comparing the 1990-2000 models, also increased (by $10 \%$ in the case of $\mathrm{SO}_{2}$ and over $25 \%$ in the case of $\mathrm{NO}_{\mathrm{x}}$ ) [4].

The situation of $\mathrm{CO}_{2}$ emissions related to vehicle production is primarily due to major material changes that have been noted in the last decades in the field of car construction. First of all, it is about the increase in the use of aluminum and its alloys, as well as a very large increase in the share of plastics and rubber in the mass of subsequent models introduced for the production of passenger cars. This increase took place at the expense of reducing the share of steel, cast steel, and cast iron. Such changes concerned and concern cars of all makes and classes [3].

The tendencies demonstrated above on the example of cars from 1990 and 2000 in the following years not only did not stop, but even experienced high acceleration. More and more new car designs are made completely or almost entirely of aluminum and its alloys. This applies not only, as before, to individual elements, but also to the whole structure of cars, their skeletons, and all elements of the cover. An example is the BMW 5 F10 Series introduced in 2010. The technique of building entire cars made of aluminum and its alloys, reserved in the nineties for super sport 
cars and the most expensive limousines (e.g. Audi A8d2 introduced in production in 1994), is increasingly used in popular cars of lower classes at the present time [5].

Life cycle analysis (LCA) is a commonly used methodology to estimate the environmental impact of any product, from the extraction phase of necessary raw materials, through the production phase, through the use phase, to the utilization phase.

The correctness of the results of such analyses is obviously dependent both on the adoption of analogous ranges of estimates carried out, as well as on similar technical and operational parameters of the tested vehicles and analogous methods of determining the data entered into the calculations. In the case of motor vehicles, it is necessary to introduce operational data for compared vehicles obtained by the same methods, that is, either from laboratory tests or from tests in real traffic. Therefore, it is necessary to use the results of tests carried out in accordance with the uniform methodology in the comparative analysis of the tested vehicles $[8,9]$.

In the case of cars with internal combustion engines, for $\mathrm{CO}_{2}$ emissions generated in the production process of the car, it is necessary to add the $\mathrm{CO}_{2}$ emission generated during their operation. Its level depends on fuel consumption, which depends on many factors alongside engine volume and its power, on the vehicle's power and aerodynamics, speed and traffic conditions, driving style (technique), tire pressure, number and degree of use of accompanying equipment, type of road surface, road conditions, etc. Currently, WLTP test procedures containing the WLTC driving cycle and emission measurements in road traffic conditions are considered to be the most reliable method for testing vehicle emissivity.

The presented comparative analysis of $\mathrm{CO}_{2}$ emissions of Ford Fiesta 1.0 EcoBoost and Toyota Corolla E12 1.6 cars was based on the WLTC driving cycle, which is an integral part of the Euro 6d-Temp homologation standard, effective from 1 September 2018.

\section{Test object}

The subject of the research was a Toyota Corolla vehicle (Fig. 1) and Ford Fiesta Ecoboost (Fig. 2). The basic vehicle data is provided in Tab. 1 and Tab. 2. Prior to the emission tests, the technical condition of both vehicles was checked. Both the Toyota Corolla, produced in 2006 and the Ford Fiesta, produced recently, passed the technical review and there were no errors recorded in the engine controllers, which proved that the exhaust gas system was working properly.

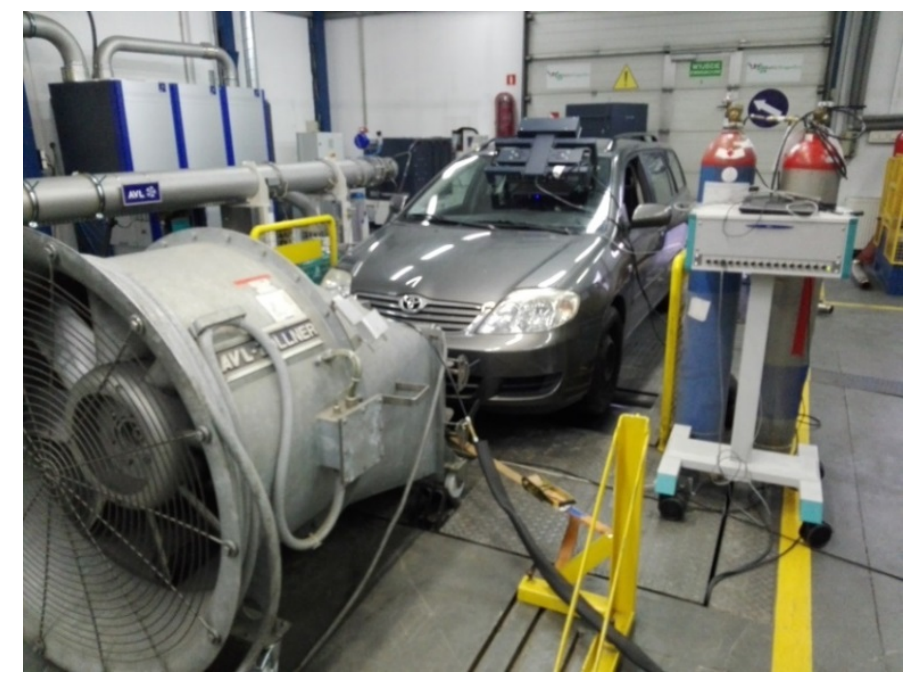

Fig. 1. Toyota Corolla car mounted on a chassis dynamometer

\section{Measuring devices used in tests}

The following set of measuring devices was used during the tests: 


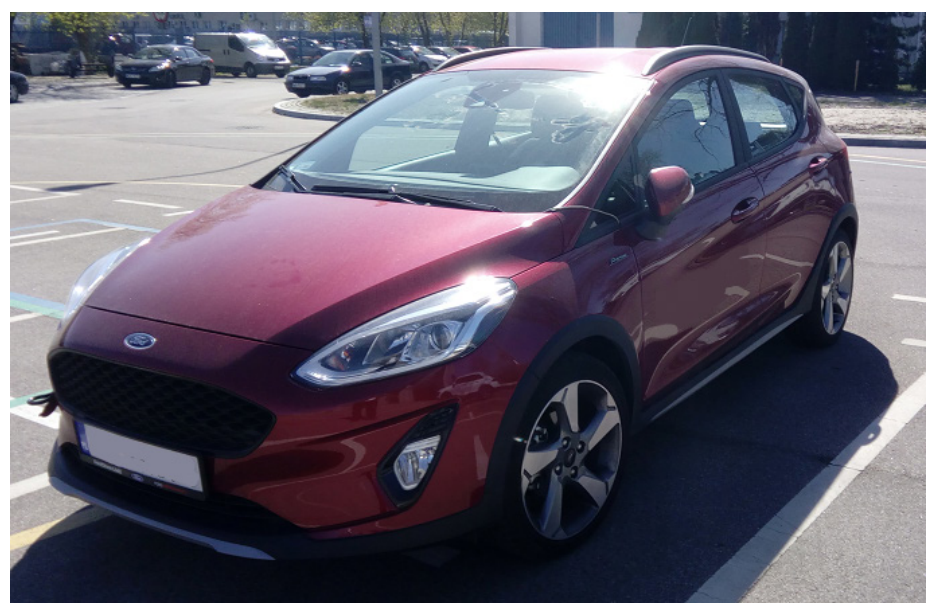

Fig. 2. Ford Fiesta test car

Tab. 1. Basic data of Toyota Corolla vehicle

\begin{tabular}{|l|l|}
\hline Make & Toyota \\
\hline Type & Corolla \\
\hline Engine displacement & $1598 \mathrm{~cm}^{3}$ \\
\hline Power / engine speed & $81 \mathrm{~kW} / 6000 \mathrm{RPM}$ \\
\hline Vehicle category & $\mathrm{M} 1$ \\
\hline Emission standard & $\mathrm{EURO} 4$ \\
\hline Maximum speed & $190 \mathrm{~km} / \mathrm{h}$ \\
\hline Odometer & $103000 \mathrm{~km}$ \\
\hline
\end{tabular}

Tab. 2. Basic data of Ford Fiesta vehicle

\begin{tabular}{|l|l|}
\hline Make & Ford \\
\hline Type & Fiesta \\
\hline Engine displacement & $999 \mathrm{~cm}^{3}$ \\
\hline Power / engine speed & $74 \mathrm{~kW} / 6000 \mathrm{RPM}$ \\
\hline Vehicle category & $\mathrm{M} 1$ \\
\hline Emission standard & EURO 6.2 \\
\hline Maximum speed & $180 \mathrm{~km} / \mathrm{h}$ \\
\hline Odometer & $12000 \mathrm{~km}$ \\
\hline
\end{tabular}

- emission measurement system manufactured by AVL:

- CFV-CVS type CVS i60 LD S2 by AVL exhaust gas collection system,

- a set of AVL AMA i60 D1-CD LE analysers equipped with two-band analysers to measure the concentrations of the following gases:

- carbon dioxide $\mathrm{CO}_{2}$,

- nitrogen oxides $\mathrm{NO}_{\mathrm{x}}$,

- carbon monoxide $\mathrm{CO}$,

- hydrocarbons THC,

- methane $\mathrm{CH}_{4}$,

- Vaisala weather station type PTU303 for measuring temperature, humidity, and air pressure during test cycles,

- single-roll chassis dynamometer with adjustable resistance curve by AVL-Zoellner to simulate the resistance of vehicle movement on the road,

- hytherograph with LAB-EL type LB-701, version M with reading panel LB-702B, for controlling and recording of environmental conditions during vehicle conditioning before tests. 


\section{Measurement results}

Measurements in the WLTC cycle were performed at the chassis dynamometer where the temperature and humidity of the air were maintained in the ranges of $23 \pm 5^{\circ} \mathrm{C}$ and $50 \pm 5 \%$, respectively. The table presents the coefficients of the motion resistance curve simulated by the dynamometer.

Tab. 3. Coefficients of the second degree polynomial of the motion resistance curve simulated by the dynamometers (absorbed force) used in the tests of both vehicles

\begin{tabular}{|l|r|r|}
\hline & Toyota Corolla & \multicolumn{1}{|c|}{ Ford Fiesta } \\
\hline $\mathrm{R}_{\mathrm{W}}[\mathrm{kg}]$ & 1360 & 1394 \\
\hline $\mathrm{F}_{0}[\mathrm{~N}]$ & 64.640 & 12.440 \\
\hline $\mathrm{F}_{1}[\mathrm{Ns} / \mathrm{m}]$ & 4.0477 & -1.4608 \\
\hline $\mathrm{F}_{2}\left[\mathrm{Ns}^{2} / \mathrm{m}^{2}\right]$ & 0.51176 & 0.47349 \\
\hline
\end{tabular}

Before the measurement, the car was conditioned for at least 12 hours.

Tab. 4. $\mathrm{CO}_{2}$ emissions from the Toyota Corolla exhaust system in the WLTC test

\begin{tabular}{|l|c|c|c|c|c|c|}
\hline No. & 1 & 2 & 3 & 4 & 5 & average \\
\hline $\mathrm{CO}_{2}[\mathrm{~g} / \mathrm{km}]$ & 161.13 & 161.06 & 161.11 & 161.15 & 161.05 & 161.1 \\
\hline
\end{tabular}

Tab. 5. The results of $\mathrm{CO}_{2}$ emissions from the Ford Fiesta exhaust system in the WLTC test

\begin{tabular}{|l|c|c|c|c|c|c|}
\hline No. & 1 & 2 & 3 & 4 & 5 & average \\
\hline $\mathrm{CO}_{2}[\mathrm{~g} / \mathrm{km}]$ & 130.65 & 130.75 & 130.76 & 130.79 & 131.15 & 130.82 \\
\hline
\end{tabular}

\section{Conclusions}

It is undeniable that newly manufactured passenger cars are characterized by lower $\mathrm{CO}_{2}$ emissions than cars manufactured 10 or 15 years ago. However, contrary to what they are trying to convey to the potential buyers the advertising and PR departments of large automotive concerns, these are not big differences. The article describes the case of two cars with similar engine power and similar mass. It turns out that the most modern automotive product meeting the Euro 6.2 standard has the emissions tested at the WLTC test of $130.82 \mathrm{~g} \mathrm{CO}_{2} / \mathrm{km}$ and Toyota Corolla from the production year 2006 meeting the Euro 4 standard has an emissivity of $160.1 \mathrm{~g} \mathrm{CO}_{2} / \mathrm{km}$. It is worth noting that the Toyota Corolla model with this engine model has been in production since 2002 and maintained in good condition should exhibit emissivity as it was found during the tests.

From the above tests and calculations made it is clear that the ecological profit of purchasing and using a modern vehicle that meets the Euro 6.2 emissions standard and replacing it with an older car complying with the Euro 4 emission standard appears only after driving a new vehicle $187000 \mathrm{~km}$. It results directly from the fact that the production process of a modern car is a seriously damaging effect on the natural environment as a result of high $\mathrm{CO}_{2}$ emissions, and the difference between the emission level of currently produced cars and the emission level of cars manufactured a dozen or so years ago is not very high.

Automotive companies that advertise the purchase of new cars as pro-ecological activity is escaping the fact or are rather not aware of this issue as a big burden for the environment is the production of a new passenger car. The presented research shows that for a wide group of users of passenger cars who use them several thousand kilometres annually, the more ecological behaviour will be the use of a previously owned passenger car while maintaining its good technical condition. Its replacement with a brand new vehicle will involve several tons of carbon dioxide emitted into the atmosphere. 


\section{References}

[1] Andersson, J., May, J., Favre, C., Bosteels, D., Vries, S., Heaney, M., Keenan, M., Mansell, J., On-Road and Chassis Dynamometer Evaluations of Emissions from Two Euro 6 Diesel Vehicles, SAE International Journal of Fuels and Lubricants, Vol. 7, No. 3, pp. 919-934, 2014.

[2] Chatzikomis, E. J., Spentzas, K. N., Mamalis, A. G., Enviromental and economic effects of widespread intoruction of electric vehicles in Greece, European Transport Research Review, No. 6, pp. 365-376, 2014.

[3] Demuynck, J., Favre, C., Bosteels, D., Hamje, H., Real-World Emissions Measurements of a Gasoline Direct Injection Vehicle without and with a Gasoline Particulate Filter, SAE Technical Paper 2017-01-0985, 2017.

[4] Eliasz, J., Mrozik, M., Wybrane aspekty dotyczace nakładów materiałowych i energetycznych $w$ fazie budowy samochodów osobowych, Autobusy. Technika, Eksploatacja, Systemy transportowe, No. 5, 2011.

[5] Menes, M., Stan i kierunki rozwoju światowego przemystu motoryzacyjnego na progu drugiej dekady XXI wieku, Zeszyty naukowe ITS, Warszawa 2012.

[6] Pielecha, J., Merkisz, J., Jasiński, R., Gis, W., Real Driving Emissions Testing of Vehicles Powered by Compressed Natural Gas, Powertrains Fuels and Lubricants, JSAE 20199011, 2015.

[7] Soo, V. K., Copston, P., Doolan, M., Interaction between New Car Design and Recycling Impact on Life Cycle Assessment, Procedia CIRP 29 pp. 426-431, 2015.

[8] Szczepański, T., Wiśniowski, P., Typowe zadania realizowane przez silnik spalinowy, Transport Samochodowy, Vol. 1, pp. 85-104, 2017.

[9] Wiśniowski, P., Ślęzak, M., Niewczas, A., Szczepański, T., Method for synthesizing the laboratory exhaust emission test from car engines based on road tests, IOP Conference Series: Materials Science and Engineering. 421. 042080, 2018.

[10] https://phys.org/news/2018-12-carbon-emissions-billion-tonnes-high.html. 